\title{
Tools for marking plant disease and pest resistance genes: a review
}

\author{
$V_{\text {Lefebvre }}{ }^{1 *}$, AM Chèvre ${ }^{2}$ \\ 1 INRA, station d'amélioration des plantes maraîchères, domaine Saint-Maurice, BP 94, F84143 Montfavet cedex; \\ 2 INRA, station d'amélioration des plantes, domaine de la Motte, BP 29, F36650 Le Rheu cedex, France
}

(Received 5 August 1994; accepted 3 January 1995)

\begin{abstract}
Summary - Genetic mapping of disease resistance genes will help improve the efficiency of plant breeding and will lead to a better understanding of the molecular basis of resistance. It requires, however, both reliable pathological tests and polymorphic genetic markers in a well-defined segregating population. In recent years, a number of different types of genetic markers have become available. The characteristics and gene-tagging efficiency of morphological and molecular markers are reviewed. Two strategies for developing markers for disease resistance genes are presented: the establishment of genetic maps with localization of major genes and QTLs; and targeting particular regions. We discuss how molecular mapping studies provide new insights on the localization and organization of the genes involved in disease resistance.
\end{abstract}

genetics / marker / mapping / disease / resistance

Résumé - Marquage des gènes de résistance aux parasites chez les végétaux. La cartographie génétique des gènes de résistance devrait permettre d'aboutir à une amélioration de l'efficacité des schémas de sélection et de mieux connaître les bases moléculaires de la résistance. Elle nécessite à la fois des tests pathologiques fiables et des marqueurs génétiques polymorphes dans une population en ségrégation bien définie. De nombreux marqueurs génétiques sont désormais disponibles. Les caractéristiques et lintérêt des marqueurs morphologiques et moléculaires sont décrits. Deux stratégies pour cartographier des régions cibles sont présentées : d'une part la localisation de gènes majeurs ou de QTLs grâce à l'établissement de cartes génétiques, d'autre part l'étiquettage direct de régions particulières. L'apport des études de cartographie sur la connaissance de la localisation et l'organisation des gènes impliqués est discuté.

génétique / marqueur / cartographie / maladie / résistance

\footnotetext{
${ }^{*}$ Correspondence and reprints
} 
CONTENTS

INTRODUCTION.

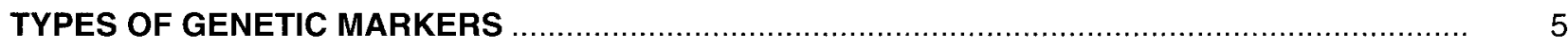

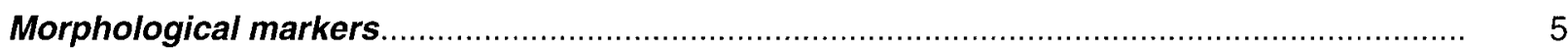

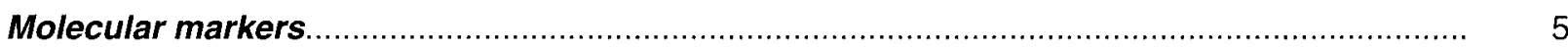

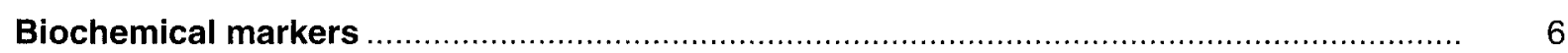

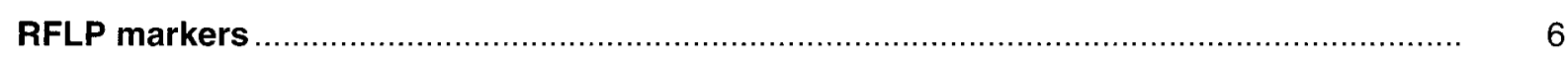

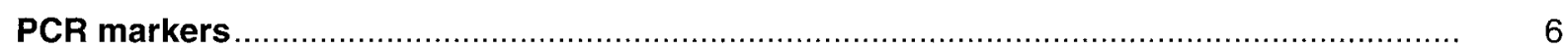

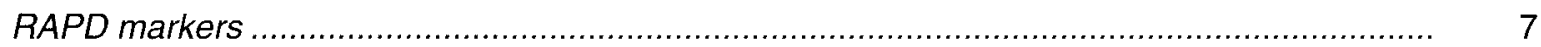

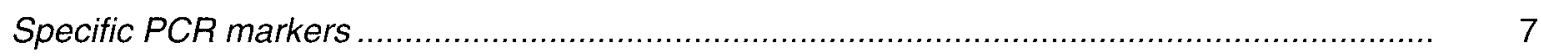

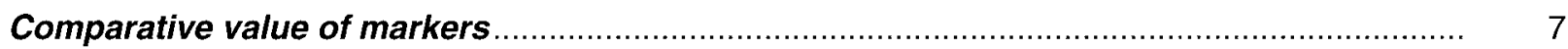

STRATEGIES FOR DEVELOPING MARKERS FOR DISEASE RESISTANCE GENES .................. 8

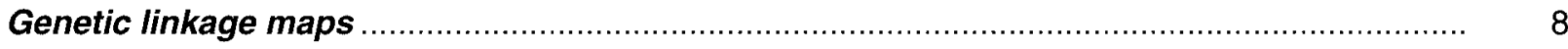

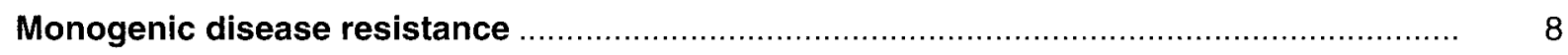

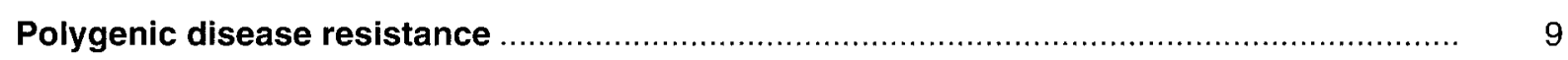

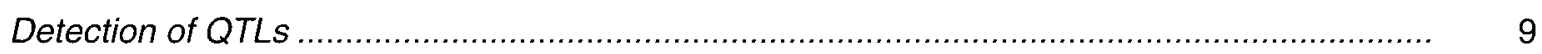

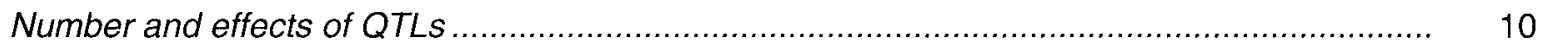

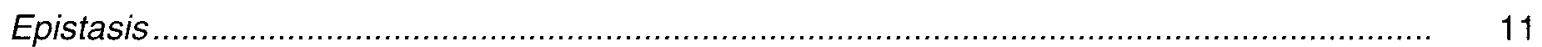

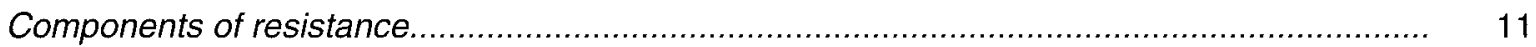

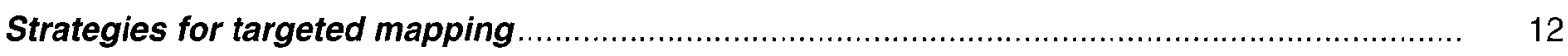

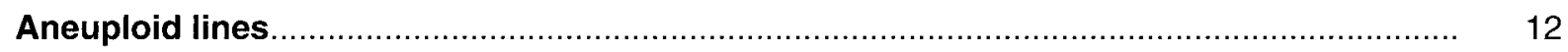

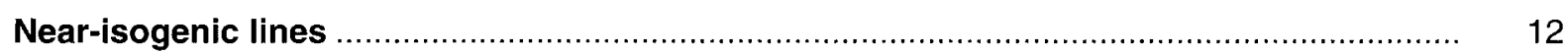

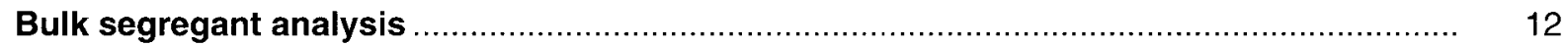

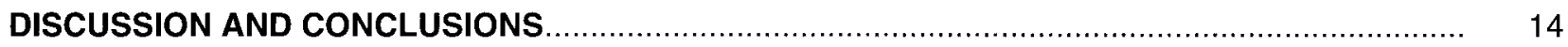

Perspectives opened by molecular mapping of resistance in plants .................................

Random or organized structure of resistance systems in plants? ....................................

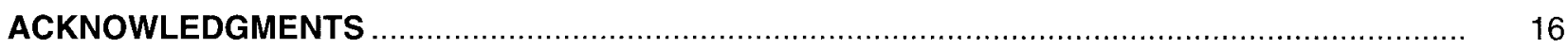




\section{INTRODUCTION}

Breeders, pathologists or entomologists will find information in this paper on the different tools used for mapping plant disease and pest resistance genes, and the most significant data obtained in this field in the last 5-10 years.

Breeding for disease resistance has greatly contributed to improving quality and yield in most crop plants and has led to the identification of genes involved in the expression of resistance and to their recombination through hybridization. These advances were in part the result of studies of pathogen variability and epidemiology. Plant pathologists and breeders have developed simple and reliable test procedures for several major crop diseases. However, diagnostic tests for insects or soil-borne pathogens, such as nematodes, are often difficult to develop due to the challenge posed by inoculum production and maintenance. Moreover, exotic pathogens may require a quarantine period or costly devices to prevent their release in the environment. Testing pathotypes, races or several pathogens on the same plant may be difficult because tests on detached organs are often not possible. In addition, selecting for disease resistance expressed at the adult plant stage is often expensive and difficult to perform.

Even though biological tests will always be needed to confirm marker-assisted selection, their utilization could be reduced by the use of molecular markers, which may greatly accelerate selection programs. Markers could also be powerful tools for genetic analysis and could supply complementary information to classical genetic analyses. The development and usefulness of markers for disease resistance relies, however, on the accuracy of the biological assays which must be sufficiently discriminating to characterize the various components of a quantitative resistance (for instance, a qualitative assay, such as resistance vs susceptibility, cannot lead to the identification of several quantitative trait loci). The understanding of the pattern of inheritance will determine the strategy to adopt in developing markers and the type and the size of the progeny to study. The origin of the resistance genes, either intra- or interspecific, will also influence the type of material to study.

Tight linkage between molecular markers and genes for disease resistance can be of great benefit to disease resistance breeding programs by allowing the investigator to follow the DNA markers through the generations rather than waiting for phenotypic expression of the resistance genes. Once a gene has been found to be linked to codominant markers, plants that are heterozygous for a resistance gene can be easily identified; it is therefore possible to introgress recessive or dominant disease resistance genes in a minimum number of generations (Tanksley, 1983; Young and Tanksley, 1989; Tanksley et al, 1989). The development of markers also allows the cumulation of several genes in multiresistant genotypes with durable resistance (multigenic resistance) and the analysis of polygenic resistance (Melchinger, 1990). Finally, DNA markers for disease resistance genes may be the starting point for cloning the genes and determining their mode of action (Martin et al, 1993).

In this review, we will summarize the main types of molecular markers that can be used for mapping genes and strategies for mapping monogenic or polygenic disease resistance will be presented.

\section{TYPES OF GENETIC MARKERS}

Nuclear genetic markers differentiate genotypes and are inherited according to the Mendelian laws of inheritance. Through their linkage to important genes, markers facilitate the detection of differences in the genetic information carried by individuals.

\section{Morphological markers}

Morphological markers generally correspond to qualitative traits that can be scored visually. They have been found in nature or as the result of mutagenesis experiments, for instance, in the tomato where more than 300 such mutants have been described (Tanksley and Mutschler, 1990). Morphological markers are usually dominant or recessive. Markers of this type have been used, for instance, the tomato $\mathrm{Tm}$-2 gene for resistance to tobacco mosaic virus (TMV) is linked to an anthocyaninless seedling marker (Robinson et al, 1970) and a peach mildew resistance gene is linked to the size of foliar glands (Connors, 1922).

\section{Molecular markers}

Molecular markers reveal polymorphism at the protein or DNA level. They include biochemical markers, DNA restriction fragment length poly: 
morphism (RFLP) (Beckmann and Soller, 1983; Tanksley, 1983) and markers obtained after amplification of a DNA sequence by the polymerase chain reaction (PCR) (Mullis and Faloona, 1987).

\section{Biochemical markers}

Biochemical markers are proteins produced by gene expression. These proteins can be isolated and identified by electrophoresis and staining. Isozymes are proteins that catalyze the same enzymatic reaction; they are revealed on electrophoregrams through a colored reaction associated with the enzymatic activity. They are the product of the various alleles of one or several genes. Monomeric (fig 1a) and dimeric (fig 1b) isozymes are the most often used because the analysis of their segregation is easier. Isozymes are generally codominant. Examples of isozyme systems routinely used in plant breeding are: isozyme Aps- 1 for its linkage to the tomato resistance to nematode (Meloidogyne spp) from Lycopersicon peruvianum (Rick and Fobes, 1974); isozyme Got2 for its linkage to the tomato resistance to Fusarium oxysporum race 3 from $L$ penellii (Bournival et al, 1989); isozyme Est5 for its linkage to the wheat resistance to Meloigogyne naasi from Aegilops variabilis ( $\mathrm{Yu}$, 1991); and isozyme EpD1 for its linkage to the wheat resistance to Cercosporella herpotrichoides from $A$ ventricosa (Doussinault, personal communication). It should be noted that, in most cases, the polymorphism of isozyme markers is rather poor within a cultivated species (eg, tomato). This explains why most of the known cases originate from interspecific crosses in which the resistance gene(s) come(s) from a wild relative.

\section{RFLP markers}

DNA RFLP is the consequence of the variation that exists in the distribution and presence (or absence) of restriction sites recognized by an endonuclease. Endonucleases recognize short (3-9 bases) sequences and, once fixed on DNA at their site, cut DNA at a fixed point from the site. A single base change in the sequence is sufficient for the enzyme to fail to recognize the sequence, and consequently to fail to cut DNA at this site. Consider 3 sites $A, B$ and $C$, in which all 3 are cut on double-stranded DNA and a base change prevents cutting at $B$ on the other doublestranded DNA. Digestion of this heterozygous individual will yield fragments $A B, B C$ from one

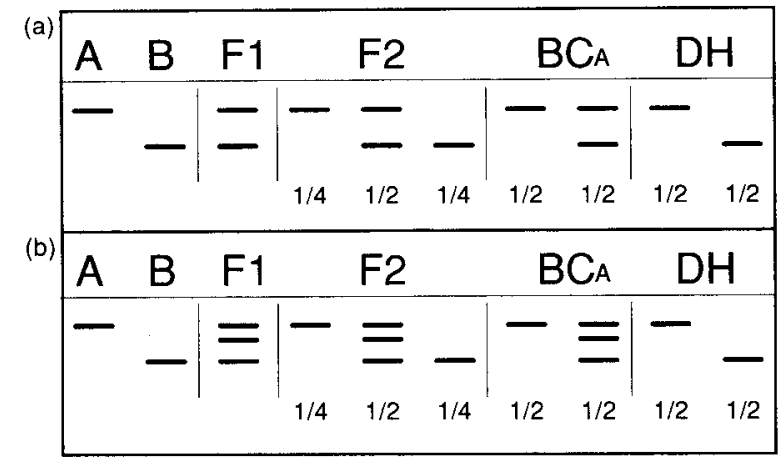

Fig 1. Example of segregation patterns and theoretical ratios (a) with a RFLP marker, with a specific PCR marker or with a codominant marker of a monomeric enzymatic system and (b) with a codominant marker of a dimeric enzymatic system according to the studied progenies issued from the cross between the parents $A$ and $B: F 2, B C$ by the parent $A$ and double haploids $(\mathrm{DH})$.

double-stranded DNA and only $A C$ from the other. Electrophoresis will reveal the difference in length between $A B, B C$ and $A C$ after hybridization with a probe, thus highlighting an RFLP that can be subjected to a linkage analysis. RFLP is thus generated whenever there is a loss or a creation of a restriction site by base substitutions, insertions, deletions, or chromosomal rearrangements. Such polymorphism can be detected by hybridization of a labelled probe to digested total DNA fragments separated by electrophoresis. Probes are preferably chosen as single copy genomic sequences or sequences with a low copy number. These markers are generally codominant (fig 1a).

\section{PCR markers}

The polymerase chain reaction (PCR) uses the property of DNA to melt or denaturate when heated in solution (ie the 2 strands separate). This provides the opportunity for copying each strand through the operation of a polymerase adding nucleotides to form the complementary strand starting from sites at which primers have recognized complementary sequences in the template DNA. A thermocycler is used to vary the temperature in the reaction tubes according to optimal specified cycles. Primers can be randomly synthesized sequences (typically decamers) or sequences determined from a known sequence. Each cycle doubles the quantity of DNA copied from the small amount present at the start, thus exponentially amplifying the DNA sequence located between the 2 known DNA primers by copying it many times (20-45 cycles of amplifica- 
tion) leading to a sufficient quantity for direct detection after electrophoresis. Hybridization of the PCR primers to template DNA occurs when the primers find complementary sequences on the template DNA at a convenient distance $(<$ 2-3 kb). RAPD (random amplified polymorphic DNA) markers or specific PCR markers can be obtained depending on the type of primers and the annealing temperature used.

\section{RAPD markers}

RAPD markers were first described by Williams et al (1990) and Welsh and McClelland (1990). They are revealed using a single type of arbitrary 10-base primer and an annealing temperature of about $35^{\circ} \mathrm{C}$. These markers cover the entire genome (single sequences to repeated sequences). One RAPD primer generally allows the amplification of several bands corresponding to several loci, which are generally dominant (presence against absence of the band). With RAPD markers, heterozygous individuals cannot be differentiated from homozygous dominant individuals. In addition, the progeny of backcrosses with the dominant parent does not segregate. Segregation patterns of RAPD markers are illustrated in figure 2.

\section{Specific PCR markers}

Pairs of specific primers 18- to 24-base long are used with an annealing temperature between 50 and $70^{\circ} \mathrm{C}$ to reveal loci. Such markers may be codominant if they reveal length polymorphism. The observed segregations will be the same as those described in figure $1 \mathrm{a}$.

Specific PCR markers can be derived from primers, which match the nucleotide sequence of the ends of a DNA fragment, eg, an RFLP probe (sequence tagged sites or STS) or an expressed sequence tag (EST) (Höfte et al, 1993). When the amplified fragment does not show length polymorphism, a restriction enzyme is used on the amplified fragment and the resulting fragments are called CAPS (cleaved amplified polymorphic region) (Konieczny and Ausubel, 1993) (fig 3). Specific PCR markers can also be simple sequence repeats (SSRs) or microsatellites which are sequences of 1,2 , or 3 bases repeated more than 10 times and bordered with unique DNA sequences. Unique flanking primers are designed from the border sequences of the repeated region and allow the amplification of a specific microsatellite. The polymorphism revealed is due to modifications in the number of repeats (Beckmann and Soller, 1990; Hearne et $a l, 1992)$ and is of the codominant type. Finally, specific PCR markers can be sequence characterized amplified regions (SCAR markers) derived from RAPD fragments from which the ends have been sequenced and used as specific primers for amplification (Paran and Michelmore, 1993). The polymorphism is directly detected in the case of length polymorphism or after enzymatic restriction.

\section{Comparative value of markers}

The comparative value of markers is described in table I. The number of available morphological and isozyme markers is generally small, except in tomato or maize. For instance, about 20 isozymes, corresponding to coding regions of the genome, are detected in most crops. Moreover, some isozyme markers dependent on the developmental stage of the plant must be assayed in specific tissues, and their expression may be conditioned by environmental conditions. DNA markers are not influenced by development or environment and generally have no effect on the phenotype. The genotype of a plant for the DNA markers can be determined at a very early developmental stage as soon as enough sample material has become available for DNA extraction. The number of observable markers is theoretically infinite. In practice, however, the number of markers is limited by the level of DNA polymor-

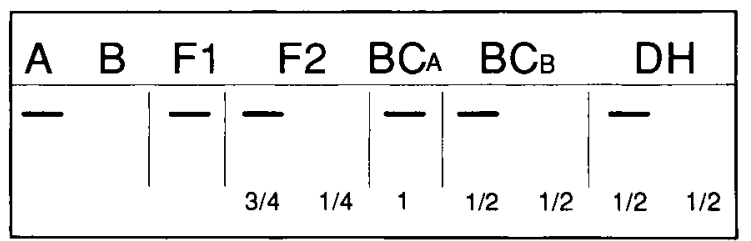

Fig 2. Example of a segregation pattern and theoretical ratios with a RAPD dominant marker according to studied progenies issued from the cross between the parents $A$ and $B: F 2, B C$ by the parent $\mathrm{A}$; and $\mathrm{BC}$ by the parent $\mathrm{B}$ and $\mathrm{DH}$.

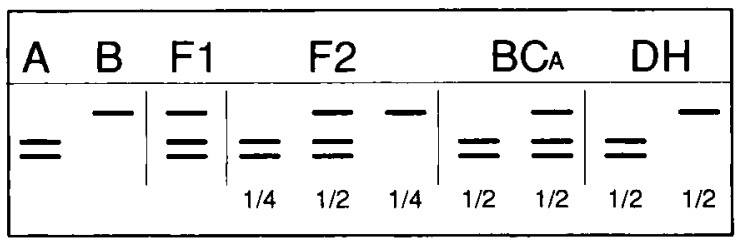

Fig 3. Example of a segregation pattern and theoretical ratios with a codominant specific-PCR marker digested with a restriction enzyme (CAPS) according to studied progenies issued from the cross between the parents $A$ and $B: F 2, B C$ by the parent $\mathrm{A}$ and $\mathrm{DH}$. 
phism that exists between the genomes of the plants. DNA markers are considered to be a class of highly informative genetic markers, particularly microsatellites.

The selection of the appropriate markers for a study depends on the level of polymorphism in the plant species in the particular crosses. Although they are less time-consuming than RFLP markers, RAPD markers have been estimated to be more expensive when large numbers of individuals and markers need to be examined (Ragot and Hoisington, 1993).

\section{STRATEGIES FOR DEVELOPING MARKERS FOR DISEASE RESISTANCE GENES}

The methods described here have the advantage of not requiring the knowledge of the gene product or expression. Identification of markers linked to disease resistance genes combines the use of detailed genetic maps and targeted mapping strategies.

\section{Genetic linkage maps}

A genetic linkage map is a graphical representation of an array of loci. Linkage maps are developed following the analysis of a large number of markers in segregating progenies of polymorphic parents. Recombination rates are used to estimate the distance between the markers. There is no precise relationship between genetic distance expressed in centimorgans and physical distance expressed in base pairs. Segregating progenies, including $\mathrm{F} 2$ progeny ( $\mathrm{F} 2$ ), backcross progeny $(\mathrm{BC})$, doubled haploid lines (DH), and recombi- nant inbred lines (RIL), are used to study recombination between markers (Allard, 1956; LefortBuson et al, 1990). Selecting the plant material depends on the biology of the species and the objectives of the study. Detailed molecular maps have been developed for several crops, including tomato (Tanksley et al, 1992), maize (Gardiner et al, 1993), and rice (Causse et al, 1994).

As mentioned earlier, classical disease resistance studies provide information on the pattern of inheritance and may be useful to select a marker-based strategy. To simplify, we will consider that resistance is either qualitatively or quantitatively expressed. The use of DNA markers to study disease resistance in plants however has been focussed primarily on single locus resistance genes.

\section{Monogenic disease resistance}

Marker-assisted selection is based on the concept that it is possible to infer the presence of a gene from the presence of a marker if a narrow linkage has been established between them. The expected proportions (probabilities) of each genotypic class for 2 independent or totally linked loci, in the F2, backcross, and doubled haploid progenies are summarized in table II. The likelihood of detecting a marker linked to a disease resistance gene is inversely proportional to the genetic distance between the marker and the gene. For a better estimate, the genetic distance between the marker and the gene must be calculated from a large population or better from several crosses. Genetic distances may greatly vary between crosses (Paterson et al, 1988; Messeguer et al, 1991).

Linkages have been frequently observed between markers and monogenic disease resis-

Table I. Comparative value of genetic markers.

\begin{tabular}{|c|c|c|c|c|c|c|}
\hline Type & Number & Determinism & $\begin{array}{l}\text { Environmental } \\
\text { effects }\end{array}$ & Locus-specific & Feasibility & Cost \\
\hline Morphological markers & Few (simultaneously) & Dominant & Yes & Yes & ++++ & Growing plants \\
\hline Isozymes & $<50$ & Codominant & Yes/no * & Yes & +++ & + \\
\hline RFLP & $\sim$ Unlimited & Codominant & No & Yes & + & +++ \\
\hline RAPD & Ｕnlimited & Dominant & No & No & +++ & $+++(+)$ \\
\hline STS/EST/CAPS/SCAR & Unlimited & Codominant & No & Yes & ++ & ++++ \\
\hline Microsatellites/SSR & -Unlimited & Codominant & No & Yes & ++ & ++++ \\
\hline
\end{tabular}


tance by mapping on a genetic linkage map. Some examples are reported in table III. isozymes, RFLP or RAPD are the most widely used markers for this strategy.

\section{Polygenic disease resistance}

Complex disease resistances (ie quantitatively expressed) are generally assumed to be under oligogenic or polygenic control (Mather and Jinks, 1971) and/or influenced by the environment. Quantitative trait loci, or QTLs (Geldermann, 1975), are considered to identify chromosome sites at which genes that have effect on quantitative traits can be located. The quantitative nature of a resistance trait would result from the simultaneous but independent allelic variation of the genes involved and the effect of the environment (Yule, 1906; East, 1915). The search for linkages between molecular markers and QTLs is based on this hypothesis.

\section{Detection of QTLS}

The detection of linkages between markers and QTLs can be performed using various statistical methods. The statistical approach using the analysis of variance estimates the degree of association between a genotypic marker (an allelic form) and a phenotypic trait. Phenotypical values are the dependent variables and the genotypic markers correspond to the treatment or the factor (source of variation). Analysis of variance models of increasing complexity provide information on the genetic basis of the resistance, for instance, the effect of individual markers (one-way Anova), the effect of pairs of markers (epistasis by two-way Anova) (Lefebvre, 1993).

The interval mapping approach (Lander and Botstein, 1989) considers linkages between markers. Using the maximum likelihood equation, the method provides an estimate, expressed as LOD score, of the likelihood of the presence of a QTL for regular intervals throughout the genome based on flanking marker information. The LOD scores actually depend not only on the localization of the QTL with respect to the flanking markers and on the magnitude of its effect, but also on the probability that there is a QTL there. While this should be kept in mind when examining the curves representing LOD, this method is very powerful, because it accounts for recombination rates between markers. To use this method therefore requires the markers to have been mapped and the trait to have a Gaussian distribution, a condition which is not always satisfied in the study of disease resistance genes (semi-quantitative data).

Analysis of variance and interval mapping are the most currently used methods. Since disease resistance is often assessed with ordinal scales and data do not always show a normal distribution, researchers have been testing putative QTLs with non-parametric statistical tests (Kreike et al, 1993; van Ooijen et al, 1993; Young et al, 1993). Other methods, using maximum likelihood, mean squares, linear and multiple regressions, have been described (Knapp, 1991; Carbonell et al, 1992; Haley and Knott, 1992; Rodolphe and Lefort, 1993).

Table II. Expected proportions of genotypical classes for 2 biallelic linked or independent loci in F2, BC and DH progenies.

Totally linked loci

\begin{tabular}{|c|c|c|c|c|c|c|c|c|c|}
\hline & $R M 1$ & $R M 1$ & $r m 1$ & $R M 2$ & $r M 2$ & $R \quad M 2$ & $r M 2$ & $R \quad m 2$ & $r m 2$ \\
\hline & $R M 1$ & $r m 1$ & $r m 1$ & - $M 2$ & $r \quad M 2$ & - $m 2$ & $r m 2$ & - $m 2$ & $r m 2$ \\
\hline & & & & & & & & & - \\
\hline $\mathrm{F} 2$ & $1 / 4$ & $1 / 2$ & $1 / 4$ & $3 / 16$ & $1 / 16$ & $6 / 16$ & $2 / 16$ & $3 / 16$ & $1 / 16$ \\
\hline $\mathrm{BCA}$ & $1 / 2$ & $1 / 2$ & & $1 / 2$ & & $1 / 2$ & & & \\
\hline $\mathrm{BCB}$ & & $1 / 2$ & $1 / 2$ & & & $1 / 4$ & $1 / 4$ & $1 / 4$ & $1 / 4$ \\
\hline $\mathrm{DH}$ & $1 / 2$ & & $1 / 2$ & $1 / 4$ & $1 / 4$ & & & $1 / 4$ & $1 / 4$ \\
\hline
\end{tabular}

M1-m1 is linked to the R-r locus; M2-m2 is not. Marker loci (M1-m1 and M2-m2) are codominant. The R allele conferring the resistance is dominant. Parental genotypes: $R M 1 / R M 1$ or $R / R$ M2/M2 for the parent $A$, and $\mathrm{rm} 1 / \mathrm{rm} 1$ or $\mathrm{r} / \mathrm{r} \mathrm{m} 2 / \mathrm{m} 2$ for the parent $B$. $B C A=(F 1 \times$ parent $A)$ and $B C B=(F 1 \times$ parent $B)$. 
Table III. Examples of marker identification for resistance genes using mapping.

\begin{tabular}{|c|c|c|c|}
\hline Host species & Pathogen & Resistance gene & Reference \\
\hline \multirow[t]{3}{*}{ Tomato } & Nematodes & $M i$ & $\begin{array}{l}\text { Rick and Fobes, } 1974 \\
\text { Messeguer et al, } 1991 \\
\text { Klein-Lankhorst et al, } 1991\end{array}$ \\
\hline & $\begin{array}{l}\text { Fusarium oxysporum sp } \\
\text { lycopersici race } 1\end{array}$ & 11 & Sarfatti et al, 1991 \\
\hline & Stemphyllium spp & $S m$ & Behare et al, 1991 \\
\hline \multirow[t]{2}{*}{ Potato } & Nematodes & Gro1, $\mathrm{H1}$ & $\begin{array}{l}\text { Barone et al, } 1990 \\
\text { Gebhardt et al, } 1993\end{array}$ \\
\hline & Potato virus $X$ & $R \times 1$ & Ritter et al, 1991 \\
\hline Pepper & Tobacco mosaic virus & $L$ & Lefebvre et al, 1994 \\
\hline Lettuce & Bremia lactucae & Several Dm genes & Landry et al, 1987 \\
\hline \multirow[t]{4}{*}{ Pea } & Pea seed-borne mosaic virus & $s b m-1$ & Timmerman et al, 1993 \\
\hline & $\begin{array}{l}\text { Fusarium oxysporum } \\
\text { f sp pisi race } 1\end{array}$ & $F w$ & Dirlewanger et al, 1994 \\
\hline & Erysiphe polygoni & er & Dirlewanger et al, 1994 \\
\hline & Pea common mosaic virus & mo & Dirlewanger et al, 1994 \\
\hline Common bean & Colletotrichum lindemuthianum & Are, $R V I$ & Adam-Blondon et al, 1994a \\
\hline Mungbean & Callosobruchus (Bruchids) & & Young et al, 1992 \\
\hline Rice & Orseolia oryzae biotype 1 (Dipteran) & $G m 2$ & Mohan et al, 1994 \\
\hline \multirow[t]{2}{*}{ Barley } & Erysiphe graminis f sp hordei & $M /-o$ & Hinze et al, 1991 \\
\hline & $\begin{array}{l}\text { Barley yellow mosaic virus and } \\
\text { Barley mild mosaic virus }\end{array}$ & $y m 4$ & Graner and Bauer, 1993 \\
\hline \multirow[t]{2}{*}{ Maize } & Maize dwarf mosaic virus & & McMullen and Louie, 1989 \\
\hline & Wheat streak mosaic virus & & McMullen and Louie, 1991 \\
\hline
\end{tabular}

With molecular markers, polygenic disease resistance can be partitioned and individual effects can be examined (components of resistance). Results of genetic studies of complex interactions have been reported, including first insect resistance in tomato (Nienhuis et al, 1987), and then quantitative resistance to pathogenic fungi and bacteria, and to nematodes (see references in the following). In addition, QTL mapping could be useful for identifying loci involved in quantitative components of resistance to viral infections such as rate of multiplication, movement in the host and disease progression. New

genes for partial resistance might be identified by this approach.

\section{Number and effects of QTLS}

Depending on the host-parasite interaction considered, from 2 (Heun, 1992; Landry et al, 1992; Bubeck et al, 1993; Freymark et al, 1993; Kreike et al, 1993; Concibido et al, 1994) to 7 (Schön et al, 1993) QTLs have been identified to explain partial disease resistance traits, confirming that these traits were under polygenic control. QTLs were generally found to be distributed across several linkage groups. 
The total phenotypic variation accounted for by QTLs is variable. In the potato cyst nematode interaction, 2 QTLs explained $14 \%$ of the phenotypic variation (Kreike et al, 1993) and 4 QTLs accounted for $75 \%$ of the variation of the resistance of bean to common bacterial blight (Nodari et al, 1993). One QTL was found to have major effects on the resistance of pea plants to Ascochyta blight (Dirlewanger et al, 1994) and on the resistance of pepper to Phytophthora root rot (Lefebvre, 1993).

Analyses have generally been conducted using $\mathrm{F} 2$ and $\mathrm{F} 3$ progenies, which allows the detection of dominance in the action of genes located at QTLs. No general rules seem to apply. While some loci have additive effects, others have partially or completely dominant ones. One case of overdominance was reported for a QTL affecting the interaction between bean and Rhizobium (Nodari et al, 1993).

Several authors have pointed out that the susceptible parent can contribute to resistance since some QTLs have been shown to have effect contrary to parental behavior (Bubeck et al, 1993; Figdore et al, 1993; Freymark et al, 1993; Lefebvre, 1993; Nodari et al, 1993; Schön et al, 1993; Young et al, 1993; Dirlewanger et al, 1994). The recombination of susceptible and resistant alleles originating from both parents may explain the occurrence of either resistant or susceptible transgressive segregants in progenies of 'resistant $x$ susceptible' crosses.

Gene mapping in different populations and environments allows the determination of the effect of the genetic background and genotype $x$ environment effects, and the detection of specific genetic factors originating from diverse sources of resistant germplasm. For instance, European corn borer resistance in maize appears to be more consistent across locations (Schön et al, 1993) than gray leaf spot resistance (Bubeck et al, 1993). Two sources of resistance to gray leaf spot resulted from different QTLs providing an opportunity for multiple resistance (Bubeck et al, 1993). To differentiate QTLs from 2 cultivars of barley with quantitative resistance to powdery mildew, Heun (1992) used a segregating $\mathrm{DH}$ population derived from a cross between the cultivars. It remains to check that the 2 resistances behave as additive.

\section{Epistasis}

A 2-factor analysis of variance can detect interactions between the genes associated with markers. This has rarely been tested. A few authors
(Bubeck et al, 1993; Kreike et al, 1993; Concibido et al, 1994) tested the interaction between 2 markers associated with additive effects at QTLs but found no significant interaction, which indicated that the loci were additive and that epistasis between the QTLs was not important. In the common bean, the frequency of significant interactions for the number of Rhizobium nodules was similar to the frequency of type I error suggesting that the interactions could represent false positives (Nodari et al, 1993). A significant digenic epistasis $(P<0.001)$ was detected for 1 couple of markers associated with resistance against second-generation European corn borer (Schön et al, 1993). Nienhuis et al (1987) also suspected additive $x$ additive epistatic interactions among 'additive QTLs'. In these studies, QTLs with exclusively epistatic but no additive or dominance effects could not be detected. Only Nodari et al (1993) tested all possible interactions of markers for the resistance to common bacterial blight in bean. Again a small proportion of interactions were significant with a threshold level of 0.05 , suggesting that interactions were not important for this trait. In our model of the resistance of pepper to Phytophthora root rot (Lefebvre et al, in preparation), we detected several significant digenic interactions $(P<0.0005)$ that can explain up to $30 \%$ of the phenotypic variation. Epistasis effects are certainly partly responsible for the difficulties of transferring polygenic resistances into improved varieties. Interactions can also occur between alleles from the resistant parent and the susceptible parent. This suggests that epistatic effects probably also contribute to the emergence of transgressive lines.

\section{Components of resistance}

Studies of the components of a host-pathogen interaction, for instance, epidemiological characters (receptivity of the plant, inducibility of the resistance, lesion number per leaf, lesion size, incubation period, symptom development, latent period, number of propagules per unit area and disease severity), have revealed QTLs for specific steps of the interaction or QTLs common to several steps. For example, in mungbeans, a QTL appeared to be specifically associated with a delay in the development of the resistance to powdery mildew (Young et al, 1993). The resistance of maize to Exserohilum turcicum appeared to be controlled by 3 QTLs affecting both lesion number and disease severity, 1 QTL affecting both lesion size and disease severity, 1 QTL specific to lesion size, and 1 QTL specific to 
disease severity (Freymark et al, 1993). The resistance of pepper to Phytophthora root rot (Lefebvre et al, in preparation) is determined by QTLs specifically affecting 1 resistance criterion corresponding to a component of the resistance or to a particular organ inoculated as well as by QTLs affecting several resistance criteria. To date, we do not know whether QTLs common to several traits result from a pleiotropic effect of a single gene or correspond to a cluster of resistance genes.

\section{Strategies for targeted mapping}

It is possible to identify markers for disease resistance genes without drawing a genetic linkage map, which is a time-consuming procedure. The direct use of markers is essentially limited to monogenic traits since it consists of identifying a particular genomic region coding for the trait. Examples (see references in the following) include studies using aneuploid lines to identify the chromosomes or chromosome arms that carry disease resistance genes, and near isogenic lines or bulk segregant analysis to identify markers located near disease resistance genes.

\section{Aneuploid lines}

Aneuploid lines are quite useful to analyze individual chromosomes. The lines may be obtained by repeated backcrossing of an interspecific hybrid with a recurrent parent. After selfing, the progeny carries the chromosomes of the recurrent parent and an additional chromosome, or pair of chromosomes, from the other parent, and the loci differentiating the 2 species are located on the additional chromosome(s). The markers are not ordered on the resulting chromosome map (eg, Chèvre et al, 1991).

Using aneuploid lines, it is possible to identify the chromosome(s) carrying resistance gene(s). Examples in the literature include nematode resistance in relatives of sugar beet (Jung et al, 1986) and wheat (Yu, 1991), and blackleg resistance in oilseed rape from related species carrying B chromosomes (Zhu et al, 1993; Chèvre et al, in preparation).

When the genes are located on different chromosomes, aneuploid lines can be used to identify the individual effects of genes or to analyze resistance that is expressed at different developmental stages (Chèvre et al, in preparation). Moreover, when related species are resistant to the same pathogen and their chromosomes are added to a susceptible genotype, it is possible, by comparison of their aneuploid lines, to determine whether a syntenic group is involved (Jung et al, 1986).

Markers for disease resistance genes on additional chromosomes can also be used to characterize translocations or recombinant resistant lines carrying extremely small introgressed chromosomal segments.

\section{Near-isogenic lines}

Near-isogenic lines differ by one or a small number of loci. They are produced by repeated backcrossing of an F1 hybrid to the susceptible parent. RFLP or RAPD analysis of these lines is a powerful tool to map resistance genes against viruses, fungi, and nematodes (table IV).

The production of near-isogenic lines is, however, time-consuming since a minimum of 6 backcrosses are required to ensure that the genomes are mostly identical except for the small target segment around the specific gene. Researchers have compared several pairs of near isogenic lines to reduce the probability of detecting false positives in regions unlinked to the target segment. Addition lines can also be used to confirm the validity of the markers. For instance, to confirm the introgression of the Mi gene from $L$ pennelli into tomato, Klein-Lankhorst et al (1991) compared pairs of near-isogenic lines with a resistant tomato chromosome 6 substitution line.

The limiting factor with the method is the polymorphism rate between the lines. Markers are frequently obtained when a resistance gene is introgressed from a related species. In this case, recombinations are known to be suppressed in genotypes heterozygous for a foreign chromosomal segment, so the size of an introgressed segment is likely to be larger in terms of DNA base pairs than the size estimated from the genetic linkage map (Klein-Lankhorst et al, 1991).

With molecular markers, it is possible to introduce Mendelian loci and to determine their relative contribution to partial resistance ( $\mathrm{Yu}$ et al, 1991). The study of segregating populations remains a requirement to confirm that the markers are tightly linked to the disease resistance gene and to define their distance and their order.

\section{Bulk segregant analysis}

This method has been developed by Michelmore et al (1991) to map Dm genes of Lactuca sativa 
conferring resistance to Bremia lactucae. With this approach, DNA samples from susceptible or resistant plants from a segregating population are bulked separately. The comparison of the bulks using RAPD or RFLP markers allows the identification of markers linked to the gene of interest. The target region is then tested against a random genetic background. The pattern obtained for an F2 population is illustrated in figure 4 .
Any segregating population (F2, BC, HD, etc) can be studied with this method. The efficiency of the analysis depends first on the polymorphism of the parents for the target region and on the size of the bulk.

The size of the bulk is based on the frequency with which unlinked loci can be detected between the bulk and on the maximum required distance between the marker and the gene. For example,

Table IV. Examples of marker identification for resistance genes using near-isogenic lines.

\begin{tabular}{|c|c|c|c|}
\hline \multirow[t]{2}{*}{ Host species } & \multirow[t]{2}{*}{ Pathogen } & Resistance gene & \multirow[t]{2}{*}{ Reference } \\
\hline & & $-\quad-\cdots$ & \\
\hline \multirow[t]{6}{*}{ Tomato } & Tobacco mosaic virus & $T m-2 a$ & $\begin{array}{l}\text { Young et al, } 1988 \\
\text { Young and Tanksley, } 1989\end{array}$ \\
\hline & Tobacco mosaic virus & $T m-1$ & Levesque et al, 1990 \\
\hline & $\begin{array}{l}\text { Fusarium oxysporum } \\
\text { f sp lycopersici race } 2\end{array}$ & 12 & Sarfatti et al, 1989 \\
\hline & Clasdosporium fulvum & $C f-9$ & van der Beek et al, 1992 \\
\hline & Pseudomonas syringae & Pto & Martin et al, 1991 \\
\hline & Meloidogyne spp & Mi & Klein-Lankhorst et al, 1991 \\
\hline Potato & Potato virus $X$ & $R \times 2$ & Ritter et al, 1991 \\
\hline Lettuce & Bremia lactucae & $D m 1, D m 3, D m 11, D m 15, D m 16$ & Paran et al, 1991 \\
\hline \multirow[t]{2}{*}{ Common bean } & $\begin{array}{l}\text { Uromyces appendiculatus } \\
\text { var appendiculatus }\end{array}$ & Up2 & Miklas et al, 1993 \\
\hline & Collethotrichum lindemuthianum & Are & Adam-Blondon et al, 1994b \\
\hline Soybean & $\begin{array}{l}\text { Phytophthora megaspersma } \\
\text { f sp glycinea }\end{array}$ & Rps1, Rps2, Rps3, Rps4, Rps5 & Diers et al, 1992 \\
\hline Rice & Pyricularia orizae & $P i-2(t), P i-4(t)$ & Yu et al, 1991 \\
\hline \multirow[t]{3}{*}{ Barley } & $\begin{array}{l}\text { Erisyphe graminis } \\
\mathrm{f} \text { sp hordei }\end{array}$ & Mla & $\begin{array}{l}\text { Schüller et al, } 1992 \\
\text { Jahoor et al, } 1993\end{array}$ \\
\hline & $\begin{array}{l}\text { Erisyphe graminis } \\
\text { f sp hordei }\end{array}$ & $m /-0$ & Hinze et al, 1991 \\
\hline & Rhynchosporium segalis & $R h$ & Barua et al, 1993 \\
\hline \multirow[t]{2}{*}{ Wheat } & $\begin{array}{l}\text { Erisyphe graminis } \\
\text { f sp tritici }\end{array}$ & Pm3 & Hartl et al, 1993 \\
\hline & Helminthosporium maydis & $r h m$ & Zaitlin et al, 1993 \\
\hline Oat & $\begin{array}{l}\text { Puccinia graminis and } \\
\text { P coronata }\end{array}$ & $P g 3$ & Penner et al, 1993 \\
\hline Maize & Helminthosporium turcicum & $H+1$ & Bentolila et al, 1991 \\
\hline
\end{tabular}


for a bulk composed of 10 plants, the frequency of false positives will vary from $2 \times 10^{-6}$ for an F2 population to $2 \times 10^{-3}$ for $\mathrm{DH}$ or $\mathrm{BC} 1$ plants. The higher the number of plants in the bulk, the lower the frequency of false positives. If the number of plants is small, the frequency of markers unlinked to the resistance gene may increase but a greater number of markers can be found. In any case, the linkage must be confirmed by the analysis of the segregating population, which will identify the false positives. The degree of linkage is finally determined according to the analysis of the segregating population. When the population is homozygous for most loci, fewer plants per bulk can be used. This was illustrated by the mapping of the Up2 gene of common bean conferring resistance to Uromyces appendiculatus with a bulk of 3 plants from a BC6F2 population (Miklas et al, 1993). The linked RAPD marker can be used to combine the Up2 gene with other rust resistance genes (Haley et al, 1993). In studies with doubled haploids, 2 strategies have been proposed: (i) to bulk more than 10 plants (as proposed by Pineda et al, 1993, who obtained RFLP markers linked with gene $\mathrm{H} 1$ of Solanum tuberosum conferring resistance to Globodera rostochiensis); or (ii) to analyse simultaneously NILs and bulks made of 5 doubled haploids or bulks of NILs (as proposed by Barua et al, 1993, who mapped the $R h$ locus conferring resistance to Rhynchosporium secalis in barley using RAPD markers, and Haley et al, 1994, who mapped the Ur-3 locus conferring the resistance to Uromyces appendiculatus in common bean also using RAPD markers).

RAPD markers appear to be more efficient than RFLP markers with the bulk segregant analysis method. Individual primers can be used to detect multiple loci with a random distribution. The sensitivity of the PCR technology is such that one recombinant in a bulk of 10 plants can be detected (Michelmore et al, 1991). SCAR markers are derived from RAPD markers in order to increase the repeatability and reliability of the latter (Paran and Michelmore, 1993).
Regardless of the marker used, polymorphism is not detected more than about $30 \mathrm{cM}$ from the target region. Bulk segregant analysis is a very efficient technique to saturate a region with molecular markers.

\section{DISCUSSION AND CONCLUSIONS}

\section{Perspectives opened by molecular mapping of resistance in plants}

The understanding of the mechanisms underlying monogenic and polygenic disease resistances is steadily progressing. In some cases, markers linked to disease resistance loci can now be used for marker-assisted selection (MAS) programs, eliminating the need for traditional disease testing procedures. Melchinger (1990) optimized a design for retaining the minimum number of individuals in each generation, relying on the recombination rate between the target gene and 1 or 2 markers. For a major resistance gene, markerbased recurrent backcross programs are frequently used (Young and Tanksley, 1989). MAS can be extremely useful to cumulate several resistance genes ('pyramiding' resistance genes). A future application of MAS will be in quantitative resistance loci. When a small number of QTLs are involved, the technique becomes similar to that used to select qualitative traits. The more loci there are segregating for a trait, the larger the number of individuals which must be characterized to have a high probability of recovering the favorable set of marker alleles at all the interesting loci. If the trait is controlled by a large number of QTLs with small effects, the probability of identifying markers linked to all the QTL is low and moreover there is a high probability of finding a single false QTL representing the resultant effect of many small effect genes dispersed on a chromosome arm (Gallais and Rives, 1993), making selection difficult. A selection index including both molecular marker information and

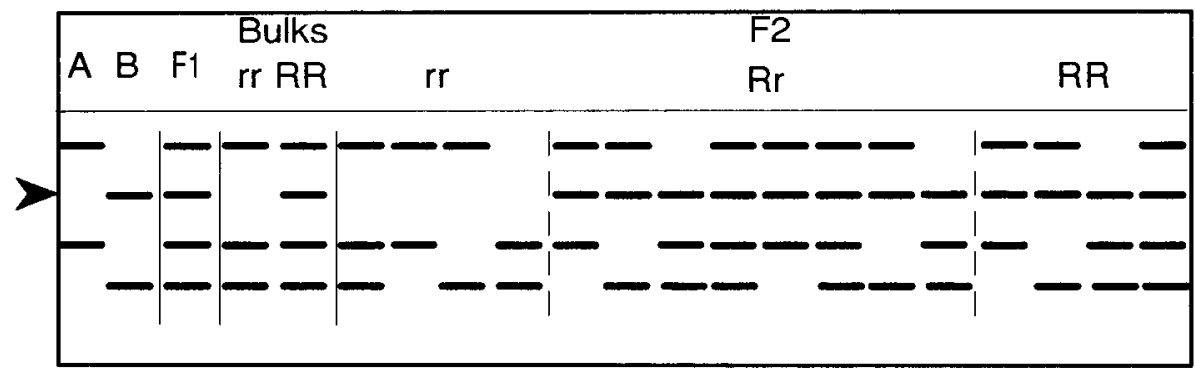

Fig 4. Example of a pattern of bulks derived from F2 individuals homozygous for resistance (RR) or susceptibility ( $r r$ ) and of the F2 individuals. The arrow shows the dominant locus linked to the allele conferring the resistance (Michelmore et al, 1991). 
phenotypic scores will produce more progress from selection than marker selection or phenotypic selection alone unless heritability of the trait is 1 (Lande and Thompson, 1990). Dudley (1993) reviewed methods and results concerning MAS for traits controlled by a large number of QTLS and discussed methods of combining data from different markers and different traits. The potential of MAS in quantitative genetics remains unclear because it depends on the relative cost and the actual complexity of molecular biology techniques. There are still technical limitations for generalizing their use everywhere (DNA extraction, Southern transfer and hybridization for RFLP). With the development of the PCR-based techniques, MAS is greatly simplified.

\section{Random or organized structure of resistance systems in plants?}

Several studies have revealed overlapping or tight linkage between resistance loci with known qualitative effects and QTLs affecting quantitative resistance. These results re-open the debate about van der Planck's concepts (1968) of horizontal and vertical resistance (Freymark et al, 1993). Nelson (1978) proposed that quantitative resistance may be the accumulation of residual effects of qualitative resistance genes that are no longer effective. More generally, Robertson (1989) suggested that genes with quantitative effects should be allelic to genes with qualitative effects. Support for this hypothesis is provided by studies of plant height in maize (Beavis et al, 1991). It is also provided by studies of Freymark et al (1993), who determined that loci in the vicinity of 3 monogenic resistance genes to Exserohilum turcicum had minor effects on 2 quantitative resistance components to this pathogen. In contrast, Heun (1992) and Kreike et al (1993) observed no residual effects of monogenic resistance loci on quantitative resistance to powdery mildew in barley (Heun, 1992) and to potato cyst nematode in potato (Kreike et al, 1993). In pea, a QTL linked to resistance to Ascochyta pisi was located near a monogenic resistance locus to powdery mildew (Dirlewanger et al, 1994). Similarly, in pepper, we found a QTL affecting the resistance to Phytophthora root rot mapping in the vicinity of the monogenic resistance locus $L$ to TMV (Lefebvre et al, unpublished). In the last 2 examples, QTLs displayed reverse effects relative to parental values. This is to be expected since the monogenic resistance and the polygenic resistance originated from different parents.

A genomic segment may be associated with several host-pathogen interactions (quantitative effects). The segment may contain multiple QTLS or a unique factor with pleiotropic effects. Such a region has been found for Rhizobium nodule number and resistance to common bacterial blight in common bean (Nodari et al, 1993). Similarly, the resistance to Phytophthora root rot and to potyviruses in pepper is influenced by common genomic regions (Caranta et al, personal communication). The results suggest that common defense mechanisms involved perhaps in 'general' resistance may operate in host-pathogen interactions. To check this hypothesis, markers corresponding to cloned disease resistance genes with a known function could be mapped and their localization compared with that of QTLs for resistance genes.

The examples cited above indicate that certain genomic regions play an important role in disease resistance. These regions may correspond to either an allelic series at a given resistance locus or a number of tightly linked loci. This may also mean that a same recognition or delivery signals may be shared by several pathogens. In addition, mechanisms to generate gene complexes probably exist. Hulbert and Bennetzen (1991) observed a very high rate of meiotic instability for the $R p 1$ genes. The instability resulted from unequal cross-over probably due to 'slippage'. Such recombinational events may be responsible for the expansion or contraction of disease resistance loci. Recombination 'hot spots' may be analogous to that observed for the human major histocompatibility complex, a genomic region encoding the mammalian immune system (Dangl, 1992). The existence of clusters of resistance genes offers an opportunity to quickly reveal markers closely linked to a new resistance gene in analyzing first the markers known to be linked to clusters of resistance genes (Maisonneuve et al, 1994).

Synteny studies (Tanksley et al, 1992; Prince et al, 1993) have made it possible to compare genomic regions involved in disease resistance in related species. For instance, a QTL for resistance to the potato cyst nematode has been mapped on potato chromosome 11, while the tomato resistance loci $S m$ and 12 are located on a tomato chromosome homeologous to potato chromosome 11 (Sarfatti et al, 1989; Behare et al, 1991; Kreike et al, 1993). Similarly, the $L$ locus for resistance to TMV in pepper is linked to 
an RFLP marker on tomato chromosome 11 (Lefebvre et al, 1994). The Gro1 resistance locus in potato (Barone et al, 1990) is closely linked to markers for the 11 resistance locus on tomato chromosome 7 (Sarfatti et al, 1991). The H1, R1 and $R \times 2$ resistance loci have been mapped on potato chromosome 5 (Ritter et al, 1991; Leonards-Schippers et al, 1992; Gebhardt et al, 1993; Pineda et al, 1993) and the tomato Pto resistance locus also maps on the homeologous tomato chromosome 5 (Martin et al, 1993). In pepper, 1 marker located on the tomato chromosome 5 is linked on the pepper map to a QTL influencing the resistance to Phytophthora root rot (Lefebvre, 1993).

Markers linked to disease resistance genes may be useful for cloning and sequencing the genes and to investigate their function. Five resistance genes have been cloned: the maize Hm1 gene (Johal and Briggs, 1992); the tomato Pto gene (Martin et al, 1993); the tomato Cf-9 gene (Jones et al, 1994), the arabidopsis Rps2 gene (Bent et al, 1994; Mindrinos et al, 1994); and the tobacco $N$ gene (Whitham et al, 1994). The last 4 correspond to the gene-for-gene model. The understanding of the function and regulation of the resistance genes and their interaction with the pathogen will be a key element in obtaining durable resistance.

\section{ACKNOWLEDGMENTS}

G Seguin-Swartz (Agriculture Canada, Saskatoon, Canada), B Landry (Agriculture Canada, Saint-Jean sur-Richelieu, Canada), A Palloix (INRA, Montfavet, France), $M$ Rives (INRA, Montfavet, France) and $G$ Doussinault (INRA, Rennes, France) are gratefully acknowledged for their critical and helpful reading of the manuscript.

\section{REFERENCES}

Adam-Blondon AF, Sévignac M, Dron M (1994a) A genetic map of common bean to localize specific resistance genes against anthracnose. Genome 37, 915-924

Adam-Blondon AF, Sévignac $M$, Bannerot $H$, Dron $M$ (1994b) SCAR, RAPD and RFLP markers linked to a dominant gene (Are) conferring resistance to anthracnose in common bean. Theor Appl Genet 88, 865-870

Allard RW (1956) Formulas and tables to facilitate the calculation of recombination values in heredity. Hilgardia 24, 235-278
Barone A, Ritter E, Schachtschabel U, Debener T, Salamini F, Gebhardt C (1990) Localization by restriction fragment length polymorphism mapping in potato of a major dominant gene conferring resistance to the potato cyst nematode Globodera rostochiensis. Mol Gen Genet 224, 177-182

Barua UM, Chalmers KJ, Hackett CA, Thomas WTB, Powell W, Waugh R (1993) Identification of RAPD markers linked to a Rynchosporium secalis resistance locus in barley using near-isogenic lines and bulked segregant analysis. Heredity 71, 177-184

Beavis WD, Grant D, Albertsen M, Fincher R (1991) Quantitative trait loci for plant height in 4 maize populations and their associations with qualitative genetic loci. Theor Appl Genet 83, 141-145

Beckmann JS, Soller M (1983) Restriction fragment length polymorphisms in genetic improvement: methodologies, mapping and costs. Theor Appl Genet 67, 35-43

Beckmann JS, Soller M (1990) Toward a unified approach to genetic mapping of eukaryotes based on sequence tagged microsatellite sites. Bio/Technology 8, 930-932

Behare J, Laterrot H, Sarfatti M, Zamir D (1991) Restriction fragment length polymorphism mapping of the Stemphillium resistance gene in tomato. Mol Plant-Microbe Int 4, 489-492

Bent AF, Kunkel BN, Dahlbeck D et al (1994) RPS2 of Arabidopsis thaliana: a leucine-rich repeat class of plant disease resistance genes. Science 265, 1856 1860

Bentolila S, Guitton C, Bouvet N, Saillan A, Nykaza S, Freyssinet $G$ (1991) Identification of an RFLP marker tightly linked to the $H t 1$ gene in maize. Theor Appl Genet 82, 393-398

Bournival BL, Scott JW, Vallejos CE (1989) An isozyme marker for resistance to race 3 of Fusarium oxysporum $f \mathrm{sp}$ lycopersici in tomato. Theor Appl Genet 78, 489-494

Bubeck DM, Goodman MM, Beavis WD, Grant D (1993) Quantitative trait loci controlling resistance to gray leaf spot in maize. Crop Sci 33, 838-847

Carbonell EA, Gerig TM, Balansard E, Asins MJ (1992) Interval mapping in the analysis of nonadditive quantitative trait loci. Biometrics 48, 305-315

Causse MA, Fulton TM, Cho YG et al (1994) Saturated molecular map of the rice genome based on an interspecific backcross population. Genetics 138 , 1251-1274

Chèvre AM, This $P$, Eber $F$ et al (1991) Characterization of disomic addition lines Brassica napus - Brassica nigra by isozyme, fatty acid, and RFLP markers. Theor App/ Genet 81, 43-49

Concibido VC, Denny RL, Boutin SR, Hautea R, Orf $\mathrm{JH}$, Young ND (1994) DNA marker analysis of loci underlying resistance to soybean cyst nematode (Heterodera glycines Ichinohe). Crop Sci 34, 240246

Connors $\mathrm{CH}$ (1922) Inheritance of foliar glands of the peach. Proc Am Soc Hort Sci 18, 20-26 
Dangl JL (1992) The major histocompatibility complex à la carte: are there analogies to plant disease resistance genes on the menu? The Plant Journal 2, 3-11

Diers BW, Mansur L, Imsande J, Shoemaker RC (1992) Mapping Phytophthora resistance loci in soybean with restriction fragment length polymorphism markers. Crop Sci 32, 377-383

Dirlewanger E, Isaac $P G$, Ranade S, Belajouza M, Cousin R, de Vienne D (1994) Restriction fragment length polymorphism analysis of loci associated with disease resistance genes and developmental traits in Pisum sativum L. Theor App/ Genet 88, 1727

Dudley JW (1993) Molecular markers in plant improvement: manipulation of genes affecting quantitative traits. Crop Sci 33, 660-668 (Errata in Crop Sci 33, 1450; Crop Sci 34, 322)

East EM (1915) Studies on size inheritance in Nicotiana. Genetics 1, 164-176

Figdore SS, Ferreira ME, Slocum MK, Williams $\mathrm{PH}$ (1993) Association of RFLP markers with trait loci affecting clubroot resistance and morphological characters in Brassica oleracea L. Euphytica 69 , 33-44

Freymark PJ, Lee M, Woodman WL, Martinson CA (1993) Quantitative and qualitative trait loci affecting host-plant response to Exserohilum turcicum in maize (Zea mays L). Theor App/ Genet 87, 537-544

Gallais A, Rives M (1993) Detection, number and effects of QTLs for a complex character. agronomie $13,723-738$

Gardiner JM, Coe EH, Melia-Hancock S, Hoisington DA, Chao $S$ (1993) Development of a core map in maize using an immortalized $F 2$ population. Genetics 134, 917-930

Gebhardt C, Mugniery D, Ritter E, Salamini F, Bonnel E (1993) Identification of RFLP markers closely linked to the $\mathrm{H} 1$ gene conferring resistance to Globodera rostochiensis in potato. Theor Appl Genet 85, 541-544

Geldermann H (1975) Investigations on inheritance of quantitative characters in animals by gene markers. I. Methods. Theor App/ Genet 46, 319-330

Graner A, Bauer E (1993) RFLP mapping of the ym4 virus resistance gene in barley. Theor Appl Genet 86, 689-693

Haley CS, Knott SA (1992) A simple regression method for mapping quantitative trait loci in line crosses using flanking markers. Heredity 69, 315-324

Haley SD, Miklas PN, Stavely JR, Byrum J, Kelly JD (1993) Identification of RAPD markers linked to a major rust resistance gene block in common bean. Theor Appl Genet 86, 505-512

Haley SD, Afanador LK, Miklas PN, Stavely JR, Kelly JD (1994) Heterogeneous inbred populations are useful as sources of near-isogenic lines for RAPD marker localization. Theor Appl Genet 88, 337-342

Hartl L, Weiss H, Zeller FJ, Jahoor A (1993) Use of RFLP markers for the identification of alleles of the
Pm3 locus conferring powdery mildew resistance in wheat (Triticum aestivum L). Theor App/ Genet 86, 959-963

Hearne CM, Ghosh S, Todd JA (1992) Microsatellites for linkage analysis of genetic traits. Trends Genet 8, 288-293

Heun M (1992) Mapping quantitative powdery mildew resistance of barley using a restriction fragment length polymorphism map. Genome 35, 1019-1025

Hinze K, Thompson RD, Ritter E, Salamini F, SchulzeLefert $P$ (1991) Restriction fragment length polymorphism - mediated targeting of the $m /-o$ resistance locus in barley (Hordeum vulgare). Proc Natl Acad Sci USA 88, 3691-3695

Höfte H, Desprez T, Amselem J et al (1993) An inventory of 1152 expressed sequence tags obtained by partial sequencing of cDNAs from Arabidopsis thaliana. The Plant Journal 4, 1051-1061

Hulbert SH, Bennetzen JL (1991) Recombination at the Rp1 locus of maize. Mol Gen Genet 226, 377 382

Jahoor A, Jacobi A, Schüller CME, Fischbeck G (1993) Genetical and RFLP studies at the Mla locus conferring powdery mildew resistance in barley. Theor App/ Genet 85, 713-718

Johal GS, Briggs SP (1992) Reductase activity encoded by the $H M 1$ disease resistance gene in maize. Science 258, 985-987

Jones DA, Thomas CM, Hammond-Kosack KE, BalintKurti PJ, Jones JDG (1994) Isolation of the tomato Cf-9 gene for resistance to Cladosporium fulvum by transposon tagging. Science 266, 789-795

Jung C, Wehling P, Löptien H (1986) Electrophoretic investigations on nematode resistance in sugar beets. Plant Breed 97, 39-45

Klein-Lankhorst RM, Vermunt A, Weide R, Liharska T, Zabel P (1991) Isolation of molecular markers for tomato ( $L$ esculentum) using random amplified polymorphic DNA (RAPD). Theor Appl Genet 83, 108114

Knapp SJ (1991) Using molecular markers to map multiple quantitative trait loci: models for backcross, recombinant inbred lines, and doubled haploid progeny. Theor Appl Genet 81, 333-338

Konieczny A, Ausubel FM (1993) A procedure for mapping Arabidopsis mutations using co-dominant ecotype specific PCR-based markers. The Plant Journal 4, 403-410

Kreike CM, de Koning JRA, Vinke $\mathrm{JH}$, van Ooijen JW, Gebhardt C, Stiekema WJ (1993) Mapping of loci involved in quantitatively inherited resistance to the potato cyst-nematode Globodera rostochiensis pathotype Ro1. Theor App/ Genet 87, 464-470

Lande R, Thompson R (1990) Efficiency of markerassisted selection in the improvement of quantitative traits. Genetics 124, 743-756

Lander ES, Botstein D (1989) Mapping mendelian factors underlying quantitative traits using RFLP linkage maps. Genetics 121, 185-199 
Landry BS, Kesseli RV, Farrara B, Michelmore RW (1987) A genetic map of lettuce (Lactuca sativa L) with restriction fragment length polymorphism, isozyme, disease resistance and morphological markers. Genetics 116, 331-337

Landry BS, Hubert N, Crete R, Chang MS, Lincoln SE, Etoh $T$ (1992) A genetic map for Brassica oleracea based on RFLP markers detected with expressed DNA sequences and mapping of resistance genes to race 2 of Plasmodiophora brassicae (Woronin). Genome 35, 409-420

Lefebvre $V$ (1993) Marquage moléculaire et analyse de résistances polygéniques : interaction piment (Capsicum annuum L) - Phytophthora capsici Leon. PhD Thesis, université de Paris XI-Orsay, France, $182 p$

Lefebvre V, Palloix A, Caranta C, Pochard E (1995) Construction of an intraspecific integrated linkage map of pepper using molecular markers and doubled haploid progenies. Genome (in press)

Lefort-Buson M, Rodolphe F, Charcosset A (1990) De nouvelles perspectives pour l'analyse génétique des caractères quantitatifs. 1. À la recherche des locus importants. Biofutur 91, 30-37

Leonards-Schippers C, Gieffers W, Salamini F, Gebhardt C (1992) The $R 1$ gene conferring racespecific resistance to Phytophthora infestans in potato is located on potato chromosome V. Mol Gen Genet 233, 278-283

Levesque $H$, Vedel $F$, Mathieu $C$, de Courcel AGL (1990) Identification of a short rDNA spacer sequence highly specific of a tomato line containing $T \mathrm{~m}-1$ gene introgressed from Lycopersicon hirsutum. Theor Appl Genet 80, 602-608

McMullen MB, Louie R (1989) The linkage of molecular markers to a gene controlling the symptom response in maize to maize dwarf mosaic virus. Mol Plant-Microbe Int 2, 309-314

McMullen MD, Louie R (1991) Identification of a gene for resistance to wheat streak mosaic virus in maize. Phytopathology 81, 624-627

Maisonneuve $\mathrm{B}$, Bellec $\mathrm{Y}$, Anderson $\mathrm{P}$, Michelmore RW (1994) Rapid mapping of 2 genes for resistance to downy mildew from Lactuca serriola to existing clusters of resistance genes. Theor Appl Genet 89, 96-104

Martin GB, Williams JGK, Tanksley SD (1991) Rapid identification of markers linked to a Pseudomonas resistance gene in tomato by using random primers and near-isogenic lines. Proc Natl Acad Sci USA 88, 2336-2340

Martin GB, Brommonschenkel SH, Chungwongse $\mathrm{J}$ et al (1993) Map-based cloning of a protein-kinase gene conferring disease resistance in tomato. Science 262, 1432-1436

Mather K, Jinks JL (1971) Biometrical Genetics. Chapman and Hall, 2nd Edition, London, UK, $382 \mathrm{p}$

Melchinger AE (1990) Use of molecular markers in breeding for oligogenic disease resistance. Plant Breed 104, 1-19
Messeguer R, Ganal M, de Vicente MC, Young ND, Bolkan H, Tanksley SD (1991) High resolution RFLP map around the root knot nematode resistance gene $(M i)$ in tomato. Theor Appl Genet 82 , 529-536

Michelmore RW, Paran I, Kesseli RV (1991) Identification of markers linked to disease-resistance genes by bulked segregant analysis: a rapid method to detect markers in specific genomic regions by using segregating populations. Proc Natl Acad Sci USA 88, 9828-9832

Miklas PN, Stavely JR, Kelly JD (1993) Identification and potential use of molecular marker for rust resistance in common bean. Theor Appl Genet 85, 745749

Mindrinos M, Katagiri F, Yu GL, Ausubel FM (1994) The $A$ thaliana disease resistance gene RPS2 encodes a protein containing a nucleotide-binding site and leucine-rich repeats. Cell 78, 1089-1099

Mohan M, Nair S, Bentur JS, Rao UP, Bennett J (1994) RFLP and RAPD mapping of the rice Gm2 gene that confers resitance to biotype 1 of gall midge (Orseolia oryzae). Theor Appl Genet 87, 782788

Mullis KB, Faloona FA (1987) Specific synthesis of DNA in vitro via a polymerase-catalyzed chain reaction. Methods Enzymol 155, 335-350

Nelson RR (1978) Genetics of horizontal resistance to plant diseases. Annu Rev Phytopathol 16, 359-378

Nienhuis J, Helentjaris T, Slocum M, Ruggero B, Schaefer A (1987) Restriction fragment length polymorphism analysis of loci associated with insect resistance in tomato. Crop Sci 27, 797-803

Nodari RO, Tsai SM, Guzman P, Gilbertson RL, Gepts $P$ (1993) Toward an integrated linkage map of common bean. III. Mapping genetic factors controlling host-bacteria interactions. Genetics 134, 341-350

Paran I, Michelmore RW (1993) Development of reliable PCR-based markers linked to downy mildew resistance genes in lettuce. Theor Appl Genet 85, 985-993

Paran I, Kesseli R, Michelmore R (1991) Identification of restriction fragment length polymorphism and random amplified polymorphic DNA markers linked to downy mildew resistance genes in lettuce, using near-isogenic lines. Genome 34, 1021-1027

Paterson AH, Lander ES, Hewitt JD, Peterson S, Lincoln SE, Tanksley SD (1988) Resolution of quantitative traits into mendelian factors by using a complete linkage map of restriction fragment length polymorphisms. Nature (Lond) 335, 721-726

Penner GA, Chong J, Lévesque-Lemay M, Molnar SJ, Fedak G (1993) Identification of a RAPD marker linked to the oat stem rust gene Pg3. Theor Appl Genet 85, 702-705

Pineda O, Bonierbale MW, Plaisted RL, Brodie BB, Tanksley SD (1993) Identification of RFLP markers linked to the $\mathrm{H} 1$ gene conferring resistance to the potato cyst nematode Globodera rostochiensis. Genome 36, 152-156 
Prince JP, Pochard E, Tanksley SD (1993) Construction of a molecular linkage map of pepper and a comparison of synteny with tomato. Genome 36, 404-417

Ragot M, Hoisington DA (1993) Molecular markers for plant breeding: comparisons of RFLP and RAPD genotyping costs. Theor App/ Genet 86, 975-984

Rick CM, Fobes JF (1974) Association of an allozyme with nematode resistance. TGC Rep 24, 25

Ritter E, Debener T, Barone A, Salamini F, Gebhardt C (1991) RFLP mapping on potato chromosomes of two genes controlling extreme resistance to potato virus X (PVX). Mol Gen Genet 227, 81-85

Robertson DS (1989) Understanding the relationship between qualitative and quantitative genetics. In: Development and Application of Molecular Markers to Problems in Plant Genetics (T Helentjaris, B Burr, eds) Cold Spring Harbor Laboratory, New York, USA, 81-87

Robinson RW, Provvidenti R, Schroeder WT (1970) A marker gene for tobacco mosaic resistance. TGC $\operatorname{Rep} 20,55$

Rodolphe F, Lefort M (1993) A multi-marker model for detecting chromosomal segments displaying QTL activity. Genetics 134, 1277-1288

Sarfatti M, Katan J, Fluhr R, Zamir D (1989) An RFLP marker in tomato linked to the Fusarium oxysporum resistance gene 12. Theor Appl Genet 78, 755-759

Sarfatti M, Abu-Abied M, Katan J, Zamir D (1991) RFLP mapping of 11 , a new locus in tomato conferring resistance against Fusarium oxysporum $\mathrm{f} s \mathrm{p}$ lycopersici race 1. Theor App/ Genet 82, 22-26

Schön CC, Lee M, Melchinger AE, Guthrie WD, Woodman WL (1993) Mapping and characterization of quantitative trait loci affecting resistance against second-generation European corn borer in maize with the aid of RFLPs. Heredity 70, 648-659

Schüller C, Backes G, Fishbeck G, Jahoor A (1992) RFLP markers to identify the alleles on the Mla locus conferring powdery mildew resistance in barley. Theor Appl Genet 84, 330-338

Tanksley SD (1983) Molecular markers in plant breeding. Plant Mol Biol Rep 1, 3-8

Tanksley SD, Mutschler MA (1990) Linkage map of the tomato ( $L$ esculentum) $(2 n=24)$. In: Genetics Maps - Locus Maps of Complex Genomes (SJ O'Brien, ed), Cold Spring Harbor Laboratory Press, USA, 6.3-6.15

Tanksley SD, Young ND, Paterson AH, Bonierbale MW (1989) RFLP mapping in plant breeding: new tools for an old science. Bio/Technology 7, 257264

Tanksley SD, Ganal MW, Prince JP et al (1992) High density molecular linkage maps of the tomato and potato genomes. Genetics 132, 1141-1160

Timmerman GM, Frew TJ, Miller AL, Weeden NF, Jermyn WA (1993) Linkage mapping of $s b m-1$, a gene conferring resistance to pea seed-borne mosaic virus, using molecular markers in Pisum sativum. Theor App/ Genet 85, 609-615 van der Beek JG, Verkerk R, Zabel P, Lindhout $P$ (1992) Mapping strategy for resistance genes in tomato based on RFLPs between cultivars: Cf9 (resistance to Cladosporium fulvum) on chromosome 1. Theor Appl Genet 84, 106-112

van der Planck JE (1968) Disease Resistance in Plants. Academic Press, New York, USA, 206 pp

van Ooijen J, Sandbrink H, Purimahua C et al (1993) Mapping quantitative genes involved in a trait assessed an ordinal scale: a case study with bacterial canker in Lycopersicon peruvianum. In: Molecular Biology of Tomato - Fundamental Advances and Crop Improvements (J Yoder, ed), A Technomic Publishing Company Book, USA, 59-74

Welsh J, McClelland M (1990) Fingerprinting genomes using PCR with arbitrary primers. Nucleic Acids Res $18,7213-7218$

Whitham S, Dinesh-Kumar SP, Choi D, Hehl R, Corr $C$, Baker B (1994) The product of the tobacco mosaic virus resistance gene $N$ : similarity to toll and interleukin-1 receptor. Cell 78, 1101-1115

Williams JGK, Kubelik AR, Livak KJ, Rafalski JA, Tingey SV (1990) DNA polymorphisms amplified by arbitrary primers are useful as genetic markers. Nucleic Acids Res 18, 6531-6535

Young ND, Tanksley SD (1989) RFLP analysis of the size of chromosomal segments retained around the $T m-2$ locus of tomato during backcross breeding. Theor Appl Genet 77, 353-359

Young ND, Zamir D, Ganal MW, Tanksley SD (1988) Use of isogenic lines and simultaneous probing to identify DNA markers tightly linked to the $T m-2 a$ gene in tomato. Genetics 120, 579-585

Young ND, Kumar L, Menancio-Hautea D et al (1992) RFLP mapping of a major bruchid resistance gene in mungbean (Vigna radiata, L Wilczek). Theor Appl Genet 84, 839-844

Young ND, Danesh D, Menancio-Hautea D, Kumar L (1993) Mapping oligogenic resistance to powdery mildew in mungbean with RFLPs. Theor Appl Genet 87, 243-249

Yu MQ (1991) Transfert des gènes de résistance aux nématodes Meloidogyne naasi et Heterodera avenae d'Aegilops variabilis dans le blé tendre. PhD Thesis, université de Rennes I, France, $145 \mathrm{pp}$

Yu ZH, Mackill DJ, Bonman JM, Tanksley SD (1991) Tagging genes for blast resistance in rice via linkage to RLFP markers. Theor App/ Genet 81, 471-476

Yule GV (1906) On the theory of inheritance of quantitative compound characters on the basis of Mendel's laws - a preliminary note. Rep 3rd Int Conf Genet, 140-142

Zaitlin D, DeMars S, Ma Y (1993) Linkage of $r \mathrm{hm}$, a recessive gene for resistance to southern corn leaf blight, to RFLP marker loci in maize (Zea mays) seedlings. Genome 36, 555-564

Zhu JS, Struss D, Röbbelen G (1993) Studies on resistance to Phoma lingam in Brassica napus Brassica nigra addition lines. Plant Breed 111, 192 197 